\title{
RESPONSE
}

\section{Communities of Advocacy, Resources and Supports in the Wake of COVID-19 Vicki Chartrand}

\section{INTRODUCTION}

The roots of anti-carceral groups in the land now known as Canada were strengthened in the wake of COVID-19, a pandemic that resulted in physical distancing and worldwide lockdowns to control its spread. While most of the nation focused on the economy, the elderly and those with pre-existing health conditions, healthcare and related equipment, as well as restrictive and punitive protections in the community, those in penal and detention institutions remained one of the most invisible and vulnerable populations to its spread. As a captive population with limited resources and support, risk of exposure for incarcerated and detained persons is heightened due to confined spaces, lack of access to personal protective equipment (PPE) and sanitizing methods, as well as grossly inadequate healthcare. The coronavirus not only created an unprecedented situation, it also highlighted the many underlying problems and inequalities of our current social and justice arrangements. Amid the pandemic, grassroots organizations and individuals across the land emerged as a community of advocacy, resource and support for those confined behind the walls. In the special edition of the Prisoners' Struggles section that follows this piece shares with readers only some of the important and incredible work that anti-carceral support groups carried out during the pandemic. Many of the initiatives and activities included solidarity strikes and actions, social media campaigns, fundraising initiatives, news releases, conferencing and interviews, videos and online speaker panels, protests and rallies, educational awareness and legal interventions among many others. ${ }^{1}$ In order to give context to these articles, I will highlight some of the issues concerning media reporting of the pandemic in Canada, focusing particularly on prisons and other carceral sites including the Laval Immigration Holding Centre. 


\section{CORONAVIRUS AND PRISONS}

As the coronavirus outbreak ramped up across Canada, provincial shutdowns were occurring by mid to late March 2020. Prisons and other detention centres were initially given little thought by the public or media. With the exception of NDP member of parliament Jack Harris ${ }^{2}$ and Senator Kim Pate, ${ }^{3}$ federal politicians paid little attention to implications and the impact of COVID-19 behind bars. On the other hand, the provincial-territorial prisons were providing temporary absences, house arrest options and release to many people incarcerated within 30 days of their release date. As a result, many of the provinces and territories saw a $15 \%$ average reduction in their prison population with Ontario reporting a reduction as high as $25 \%$ within months of the pandemic having been declared (Ling, 2020a). ${ }^{4}$

As opposed to releasing people, the Correctional Service Canada (CSC) focused on curtailing the spread inside the prisons by suspending visits, all temporary absences (ETAs/UTAs) unless medically necessary, work releases, and all inter-regional and international transfers. These restrictions began easing slowly in early June. CSC (2020) also claim to have issued protective equipment (PPE) procedures, enforced hand hygiene sanitation and disinfection practices, and to have medically isolated anyone with the viral symptoms. As a result, people in federal prisons were often in lockdown 23 hours a day with no access to the library, gym, cafeteria, programs or visits from outside groups, and were only allowed one hour a day outside (NAACJ, 2020). Following this, there had also been reports of forced interventions with the use of compression grenades and plastic bullets when individuals were climbing barricades or refusing to return to cells, including incidents at Collins Bay in Ontario and Donnacona, Quebec (ibid). Despite restrictive interventions and repression, prisons remain rife with all the conditions that foster the spread of coronavirus. Consequently, COVID-19 had greatly spread throughout several federal prisons, including Port-Cartier and Joliette in Quebec, Grand Valley in Ontario, Mission in British Columbia, as well as provincial prisons such as Bordeaux in Quebec and Brampton in Ontario.

At the Laval Immigration Holding Centre for migrant detention, detainees carried out an eight-day hunger strike from March 24 to April 1 2020 to peacefully protest their confinement. A week prior to the hunger strike, the detainees had sent letters to Public Safety Canada demanding 
to be released due to COVID-19. The letter outlined risk factors including the crowded living conditions, as well as lack of adequate support, health care and legal counsel as a result of cancelled visits. Some of the hunger strikers were released as a result and the Canadian Border Services Agency released nearly half of the immigration detainees held in provincial jails and immigration holding centres by the end of April 2020 (Browne, 2020). Released migrants nonetheless remain under threat of deportation, often living with no housing, work permits or support programs.

Since the outbreak, there has been two federal carceral deaths: one at Mission Institution in April 2020 and the other at the Federal Training Centre in Laval in May 2020 (Ross, 2020)..$^{5}$ A lawsuit has been filed by an individual held at Joliette Institution for Women in conjunction with the Canadian Civil Liberties Association, the Canadian Prison Law Association, the HIV \& AIDS Legal Clinic of Ontario and the HIV Legal Network. The court challenge outlines that physical distancing measures in prison have been grossly inadequate and that restrictive interventions do not keep prisoners safe because a prison cannot ensure the proper physical distancing without reducing the prison population. The court challenge further argues that CSC have a duty of care and, in the context of COVID-19, this includes "taking immediate and proactive measures to depopulate its institutions to the greatest extent possible, consistent with public safety... Unlike other correctional authorities around the world and across Canada, however, CSC has taken few if any steps to release prisoners from its institutions" (Ling, 2020b). According to the Office of the Correctional Investigator (2020, p. 4-5), the federal prison watchdog, complaints from CSC penitentiaries include staff not wearing proper protective gear or practicing safe physical distancing, loss of yard time, lack of access to programs, chaplaincy and overall restrictive routines and conditions of confinement. There has also been an increase of incidents including protests, threats against staff, assaults on prisoners, hunger strikes and other disturbances. Compounded with the threat of the COVID-19 virus spreading, these restrictive and isolating measures have had significant impacts on the mental health and emotional well-being of those on the inside living under these severe conditions. 


\section{CONCLUSION}

Ruth Gilmore (2007) suggests that the goal of abolition and anti-carceral work is not simply about the elimination of prisons, but to address the conditions that lead to incarceration. The initiatives and testimonials in the Prisoners' Struggles section below not only highlights the draconian conditions prisoners of the Canadian carceral state face and the prisoner solidarity work that has emerged to combat them, but also reflects the pursuit of inclusivity that disrupts the dispossession characteristic of the carceral spaces and practices noted above.

Highlighted by the pandemic is the fallacy of ethical incarceration and detention - that any kind of on-going confinement can provide the resources and supports needed to face life's struggles, whether it be adequate health care or any other life support system such as mental health care, housing, education, employment, skill development, literacy, socializing, family support, and many others. The coronavirus was not the initial motivator of the anti-carceral work. Rather, anti-carceral work is a natural response to the unnatural conditions that all forms of containment create.

\section{ENDNOTES}

1 For more information on some of the initiatives that were carried out throughout the heights of the pandemic visit the following news and social media sites: https://nsadvocate.org/2020/04/26/press-release-freethemallcaravan-from-halifax-

to-vancouver-demands-prisoner-releases/, https://www.thespec.com/news/hamilton-region/2020/04/13/

demonstration-in-solidarity-with-inmates-at-barton-street-jail.

html?utm_source $=$ facebook\&source $=$ the $\% 20$ hamilton $\% 20$ spectator\&utm medium $=$ SocialMedia\&utm_campaign $=\& u t m \_$campaign_id $=\& u t m \_$content $=$, https://epic.noblogs.org/free-them-all, https://www.solidarityacrossborders.org/en/freethemallcaravan, https://www.facebook.com/CPEPgroup/photos

/a.353260231453610/2979492605497013, https://twitter.com/hashtag/FreeThemAllCaravan?src=hashtag_click, https://twitter.com/critcrim/status/1251611338998087680, https:/globalnews.ca/news/6861756/canada-releasing-immigration-detaineescoronavirus-covid-19/, http:/tpcp-canada.blogspot.com/2020/04/prison-justice-organizers-respond-to-bc.html, https://cp-ep.org/email-zap-campaigns/, https://cp-ep.org/free-calls-for-prisoners/, 
https://cp-ep.org/protectprisoners/, https://interagencystandingcommittee.org/system/files/2020-03/IASC $\% 20$

Interim $\% 20$ Guidance $\% 20$ on $\% 20$ COVID- $19 \% 20-\% 20$ Focus $\% 20$ on $\% 20$

Persons\%20Deprived\%20of\%20Their\%20Liberty.pdf, https://www.gofundme.com/f/prisoner-emergency-support-fund, https://www.gofundme.com/f/prairie-province-prisoner-support-fund, https://www.facebook.com/events/223182082120384, https://www.facebook.com/watch/?v=1972312409579083, https://www.facebook.com/events/345679286397980/, and https://

www.facebook.com/CPEPgroup/videos/453013132230766/

UzpfSTExNDc2MTEyODcyMDYxNToxMzI3Mzc4MDIwNzkyMjQ3/. See https://jackharris.ndp.ca/Blair-federal-prison-inmates.

See https://sencanada.ca/media/366200/senpate_nr_2020-03-13_coronavirus_e.pdf.

4 While most provinces and territories instituted temporary absences from their jails and prisons to reduce the risk of COVID-19 transmission, the federal government suspended them.

5 For the Mission Institution death, an application was filed for a public coroner's inquest that was supported by 38 organizations (see https://bccla.org/wp-content/ uploads/2020/04/Call-for-inquest-in-Mission-death-FINAL.pdf).

\section{REFERENCES}

Browne, Rachel (2020) "Canada is releasing immigration detainees at 'unprecedented' rates amid COVID-19 fears", Global News - April 25. Retrieved from https:// globalnews.ca/news/6861756/canada-releasing-immigration-detaineescoronavirus-covid-19/.

Gilmore, Ruth Wilson (2007) Golden Gulag: Prisons, Surplus, Crisis, and Opposition in Globalizing California, Berkeley: University of California Press.

Ling, Justin (2020a) "COVID-19 spurs prison reform from provinces but federal government slow to act", National Post, April 16. Retrieved from https://nationalpost. com/news/covid-19-spurs-prison-reform-from-provinces-but-federal-governmentslow-to-act.

Ling, Justin (2020b) "Canada Has Failed to Protect Inmates from Pandemic, Lawsuit Alleges", Vice - May 13. Retrieved from https://www.vice.com/en_ca/article/ ep44aa/justin-trudeau-canada-has-failed-to-protect-inmates-from-pandemiclawsuit-alleges.

National Associations Active in Criminal Justice [NAACJ] (2020) "Notes from a Tele/ Web conference: 13-14h, Wednesday 6 May 2020: Residential Services (CommunityBased Residential Facilities \& Healing Lodges)", Questions from NGOs to Federal Partners re: COVID, Corrections and Criminal Justice, Ottawa: NAACJ.

Ross, Salena (2020) "A second inmate in a Canadian federal prison has died of COVID-19”, CTV News - May 5. Retrieved from https://montreal.ctvnews.ca/asecond-inmate-in-a-canadian-federal-prison-has-died-of-covid-19-1.4926031. 